\title{
Unethical Practices among Journalists and the Nigerian Public Sphere
}

\author{
Bello Semiu, Crescent University, Nigeria \\ Adejola Aminat, Crescent University, Nigeria \\ Jamiu Folarin, Nigeria
}

\begin{abstract}
Over the years, the question of unethical practices among journalists in Africa and Nigeria in particular is such that has continued to attract attention and generate issues of various sorts. Despite the legal framework and regulatory bodies such as Nigerian Press Council (NPC), Nigeria Union of Journalists (NUJ) and other professional associations to checkmate the excesses of journalists, the efforts seem unyielding as these practices continue to generate multiple images about journalism and journalists alike before the Nigerian publics. Rather than enjoying public trust and confidence, skepticism and uncertainty have dominated the Nigerian public sphere regarding journalists. Hence, this paper takes a theoretical approach to examine the question of unethical practices among Nigerian journalists, giving a conceptual clarification and historical framework in order to make the paper a scholarly piece.
\end{abstract}

Keywords: Ethics, Public Sphere, Public Opinion, Unethical Practices, Journalism 


\section{Introduction}

Journalism as a profession has always been described as the 'Fourth Estate of the Realm," coming after such realms or institutions as the Executive, the Legislative and the Judiciary. Government derives its legitimacy from the people via the constitution so also do the media or journalism profession. This is the only profession having its obligations clearly expressed and stipulated in the 1999 constitution of the Federal Republic of Nigeria. This constitutional responsibility as outlined in the chapter 2 of the 1999 constitution and specifically section 22 of this chapter gives some obligations to the press. It states in part that:

The press, radio, television and other agencies of the mass media shall at all times be free to uphold the fundamental objectives contained in this chapter and uphold the responsibility and accountability of the Government to the people.

No wonder that the foremost third American President and a great philosopher of his time, President Thomas Jefferson once remarked that:

... since the basis of democracy was the opinion of the people, the very first objectives was to keep it right If it were left for me to decide whether we should have a government without the press or the press without the government, I should not hesitate a moment to choose the latter (Cited in Akinfeleye, 2005:4)

The power of the media is the power of journalists. As a result of the enormous power vested on this profession; it will no doubt have its own share of the resultant effect of the ills in the society. That is why complains about the portrayal of events, people, ideas (ideology) and places by journalists has been on the increase. Therefore, there have been constant calls from various quarters to checkmate the excesses of the gentlemen of the press.

In another dimension, journalists have received acceptance and accolades in the country and outside by virtue of the professional excellence exhibited in the course of their duty. One of the recent achievements is the Pulitzer prize (for best journalist in the world) awarded to a Nigerian journalist, Dele Olojede. In view of this, former Director General of the National Orientation Agency, Alhaji Idi Muhammad Faruk submitted that:

Most Nigerians perceive the Nigerian press positively and this is evident in increase readership, viewership, and listenership of Newspaper, Television and Radio...unfortunately, quacks and charlatans have infiltrated the ranks, thereby dragging the reputation of the profession to the mud. They are in every Press conference, offices, and airport etc demanding 'brown envelopes'. They have also introduced blackmail, using 
mobile phone and at this level of operation the demand is not brown envelop but Ghana must go!

Day (2006) shares similar view when he said that 'public opinion polls continue to disfavor the unethical behavior of journalists. This then poses a question on their credibility which tilts the public perception to hold that media ship is sailing without a moral compass'. He further quotes Rabinowitz (2006) as saying 'many journalists continue to believe that they are involved in a calling so high as to entitle them to rights not given to ordinary citizen'.

That is why there has been increasing public debates about the unethical behaviors of journalists as observed among some media practitioners. These include among others bias, press cynicism, media manipulation, condemnation of journalist intrusions into privacy, worries about the damaging or distortive effects of the television medium as levied against the gentlemen of the press, (Kieran 2003). Other and similar unethical practices among some journalists include sensationalism, fakery, plagiarism, moonlighting, corruption, junkets and check book journalism. Describing the imminent implication of these unethical practices among journalists the profession and media organizations, Potter, (2006) espouses:

Ethical lapses do occur in journalism. Reporters have accepted payments from sources. News organizations have published advertisements in the guise of news. When this happens, the public has a right question everything that appears in the news media. All journalists and all news organizations, suffer when journalists behave unethically because that behavior calls the professions credibility into question. When credibility suffers, so does a news organization ability to survive economically.

In his comparative analysis on the consequence of unethical behaviors among journalists Wilmot (2006) holds that:

You have a choice; you can work in a supermarket, a bank, or a surgery. As long as you choose to do a job where truth is the measure of professionalism, you must resist-whatever the sacrifice. You cannot offer the excuse that you tell lies to feed and house your family because by lying to defend a disastrous government you sacrifice the futures of your children and grandchildren. Doctors, architects, builders and other professionals have codes of conduct as well as professional competence, violation of which leads to deaths and collapse of buildings. Doctors, lawyers and engineers can be sued or jailed for professional malpractices. But when broadcasters and their journalists and intellectuals lie they threaten the whole societies with collapse

Consequently, media consumers do not regard journalism high but with suspicious and distrust. They are suspicious of journalists and the way they practise their trade. They give no 
distinction between journalist and politician, as disreputable, untrustworthy and dishonesty, pushing personal or sectional interest rather than the fact of the case. If people are told that the essence of journalism is truth-telling, they will react with some skepticism or derision. If they are told that the practice of journalism is founded on ethical principles of truth and objectivity they will either laugh or if they are prepared to take the matter seriously, point out that the typical tabloid story is trivial, scurrilous or invented. (Belsey 2003: 1)

Citing Samuelson (2004), Day (2006) said:

...in 1985, 65 percent of the public believe news organizations usually got their fact straight, according to the Pew Research Center, by 2002, that figure has declined to 35 percent. In 1985 the public viewed the media more 'moral' by a better than four to one margin, by 2003 public opinion was almost evenly divided on this issue.

However, it must be noted that ethical problems in media practice do not exist in isolation but exist as part of the overall ethical issues and problems in a society. Every society has it moral problems, because the journalist is a member of the society and the media is just one of the many social institutions that constitute the social system.

Therefore, any meaningful discussion of ethical problems in mass communication practice must take into consideration the ethical issues and problems in the particular society within which the mass media operate.

It is not that there is a different and competing image of journalism. But there have always been journalist who stand out from the crowd because their virtue (if not always their judgments) seems unimpeachable. (Kieran 2003:3). Before the journalist can play any significant role in the society, people must have confidence in him. This means that the media must possess high degree of credibility. This view was re-echoed by Robert Murphy when he said:

The responsibility of the media practitioners to themselves and to the society is to maintain credibility. To be effective, they must be believable and be believed. If the public does not trust the media, it has nowhere else to turn for information about public affairs.

(Cited in Bernard 1983: 100).

Moreover, it is crystal clear that the impression or opinion a person has of the reporter on the beat or place of journalistic assignment is the impression he/she carries about the 
organization the journalist stands for or represents. The journalism profession is one guided by ethics, conscience and code of conduct, therefore; to be unethical in journalism is to abuse the power of the mass media as the most potent tools for the dissemination of ideas and information in the modern world. Moreover, since journalists serve the public directly; they should be made accountable to the public for their behaviors. (Okunna, 2003, p.,112). In the recognition of the above assertion, the preamble of the code of ethics for Nigerian journalists reads:

Journalism entails a high degree of public trust. To earn and maintain this trust, it is morally imperative for every journalist and every news medium to observe the highest professional and ethical standards. In the exercise of these duties, a journalist should always have a healthy regard for the public interest.

That is why the public opinion and the entirety of public sphere should not be taken with levity because it is highly essential in any society. No doubt, favorable public opinion sells products just in the same way as it help to give a profound providence to the practice of journalism. On the other hand, unfavorable public opinion can be the kiss of death for a product, an individual or an institution (Raufu 2005:143).

Therefore Walt Seifert, a Public Relations educator in the United States of America once submitted that the supreme court is not the highest court in our land... the highest court is the court of public opinion'. In a related view, one time President of the United States, Abraham Lincoln said:

Public sentiment is everything. With public sentiment nothing can fail, without it nothing can succeed. He who moulds public sentiment goes deeper than he who executes statute or pronounces decisions. He makes statue and decisions possible or impossible to execute (Ibid).

It is on this note that this theorization examines the consequential effects of the unethical practices of Nigerian journalists in the face of public sphere. This will go a long way in reviewing the status quo, knowing where the problems lie and determine the future direction of the noble profession in Nigeria and beyond. 


\section{Brief Historical Foundation}

In order to properly address this discourse, it is essential to give a brief historical background of the code of ethics and regulatory bodies/mechanism for journalists in Nigeria. This is because ethics generally is an epiphenomenon to many professions and avocations.

According to MacBride et al, (1981) as cited by Okunna (2003), the first press council in the world was established in Swedish in 1916 and it is referred to as the court of honor. The Swedish Press Council has functioned remarkably well, and is often cited as the basis for the establishment of press council as self regulatory mechanism in other parts of the world.

Regulatory framework known differently as press councils, media councils or media ombudsman were created to address media misconducts as well as interpreting the normative principles underlying good and ethical-based journalism (Odunewu, 2000:269).

The non-statutory mechanism seemed to be preferred mode in Europe and other developed countries with long history of media liberalism, while the statutory regulatory model seemed to be prevalent in countries with emergent mass media culture which Nigeria falls into. As a result of the criticism of bias, unfairness and intrusiveness leveled against journalists, hence the formation of the ethical guidelines or code of conduct.

In Nigeria and other parts of the world, ethics being a set of rules of behavior or moral principles that govern a profession are codified into what we call code of conduct. Indeed the first set of code for the Nigeria journalists was called code of ethics. It was fashioned by the Nigeria Editors in 1962. This was later to be refined in 1979 by the combined efforts of Nigeria Union of Journalists; the Guild of Editors and the Nigerian Proprietors Organization under the Umbrella of Nigeria Press Organization. This was called code of conduct, (Bunuola 2005: 3) Since its establishment as an umpire of journalism profession or the media industry, the Nigeria Press Council had received complaints from the public about the ethical practices of Nigerian journalists and medial houses, and decisions are taken by it. 


\section{Theoretical Framework}

The framework of theories to support this study is based on four theoretical models viz: ethical theories, theory of perception, normative theory of the press and theories of media effect. The diversity in school of thoughts of what ethics really is, in general, and whether all codes guiding journalism in Nigeria must be adhered to at all times and circumstances, in particular, is the reason why the theoretical framework of this study is going to be majorly based on ethical theories. Ethical theories provide strong and effective positions from which to consider important ethical decisions which are generally important to the study of public sphere of ethical behavior of journalists.

According to Rossouw (1994) as cited by Okunna (Op.cit p.14), ethical theories are theories about justifying our moral actions. To justify simply means 'to propose reasons for' or 'to explain'. Generally, an ethical theory can be defined as a principle put forward to explain, describe, prescribe or predict human ethical behavior. Also, citing Merrill and Lowenstein (1979), Okunna (Ibid. p.16) said there are various reasons why different theories of ethics have been developed. These classes of argument are proposed or adopted by Merrill (1974): teleological and deontological theories; Theroux (1980)- Consequentialist and Nonconsequentialist (which is the same as above but only with different labels); Pratt (1988), Osos (2000) and Day (2006) added situational ethics. Rossouw (1994) identifies Consequential based theories- teleological theories and principle based theories-deontological theories. Others include Absolutist and Relativist theories, Objectivist and Subjectivist theories, Legalistic and antinomian theories (Okunna Op cit P.20).

Furthermore, Dominick (2005:420) gave five major types of ethical theories which he labeled as: the principle of the golden mean (virtue theory), Categorical Imperative, (Deontology), Principle of Unity (teleological theory), veil of ignorance, and principle of SelfDetermination. However, this paper discusses the major ethical theories as they relate to the ethical behaviors among journalists and how this could affect the perception of the public. Therefore, the theories that will be explored in this study are: Teleological theory, Deontological theory, and Relativist theory. It must be mentioned that almost all other theories in one way or the other fall under this category. 
Teleological Theory (The end justifies the means)

This Teleological theory can also be referred to as consequentialist ethics or hindsight ethics. This theory according to Day (2006:62) is predicated on the notion that the ethically correct decision is the one that produces the best consequence. Okunna, (op.cit.p.21) defines it in terms of the good produced as the consequences of an action. She stated further that in any situation, one should calculate the possible consequences of performing various actions relevant to that situation and choose the one that will produce the greatest ratio of good over evil. However, there are two different views about whose good should be promoted, thus two school of thought on teleological theory emerged- which are both regarded in their extremes. These are:

Egoism: This is based on self interest and maximizing good consequence for oneself The ethical egoist...believes that an action is right if the consequences or results of that action are good or beneficial to him or her, irrespective of the effect of the action on other people. In other words, egoism advocates that one should promote one's own good. (Ibid)

Therefore if a journalist takes an action that is aimed at producing consequences that will benefit the journalist personally, (such as slanting a news story in order to get a 'brown envelop' or contract), such a journalist is an egoist.

Utilitarianism: This is the other extreme of teleological theory. It is also referred to as social ethics or ethical universalism. It was popularized by both Jeremy Bentham (1748-1832) and John Stuart Mill (1806-1873). Utilitarianism in contrary to egoism, is defined as "at greatest benefit for the greatest number...determining what is right or wrong by considering what yield the best ratio of good to bad for the general society".

Dominick (2005: 420.) This is the type of ethical consideration the general public usually uses as yardstick in measuring the ethical behavior of journalists - to be either ethical or unethical.

Deontological Theories (The ends do not justify the means)

It is also referred to as Non-consequentialism or the categorical imperatives, duty ethics or absolutist theory. Deontological (derived from the Greek word deon or 'duty' or what ought 
to be done') theory was propounded by a German philosopher Immanuel Kant (1724-1804). In the words of Day (2006), prohibitions against certain kinds of behaviors apply, even if beneficial consequences would result. Rather than focusing on the consequence (after all, foul deeds might produce good results), deontologists emphasize the commitment to principles that the moral agent would like to see applied universally, as well as the motive of the agent... duty-based theories do not approve of using foul means to achieve positive ends.

The deontologist in journalism recognizes that certain actions, like sycophancy and acceptance of 'brown-envelopes', are intrinsically wrong, whether the consequences of such actions are beneficial or not. Similarity, such a journalist accepts that truth telling is basically right irrespective of its consequences.

\section{Relativist Theory/Situational Theory}

This is also referred to as 'Synthesis ethics' or 'compromise ethics'. It is the anti-thesis of absolutism theory (which has been discussed early with deontological theory). For the ethical relativist, what is good or bad is relative to a number of considerations and circumstances. To properly understand the ethical theory of relativist or situational theory and its relationship with this study the views of both Okunna (op cit) and Merril (1974) are of great importance.

According to Okuuna, the relativist in journalism would argue, for instance, that Nigerian journalist and their American or British counterparts should not be judged by the same ethical standards, in views of their different situations and the contrasting environments within which they operate. For such a relativist, it would not be unethical for a middle aged male Nigerian journalist to accept 'brown envelopes' as a prerequisite for performing his journalistic duty.

How else would he, given his meager salary and the terribly poor economic situation in this country, provide for his wife (or wives), many children and large extended family? For this relativist, an American journalist would have no 'justification' for behaving like his Nigerian counterpart, and his accepting a 'brown envelop' would definitely be unethical. Fortunately, however, both international code and the code of ethics for Nigerian journalists condemn the 
acceptance of all types of bribe by journalists..., signifying a universal rejection of ethical relativism in journalism.

In his own description of Situational ethics, Merrill (1974) writes:

The situationist journalist may well be the one who believes that he should tell the truth as a basic principle or that he should not generally distort his story, but who will after due consideration of the situation in which he finds himself, conclude that it is alright to distort this particular story or even to lie- he is one then who takes special situations into consideration in making his ethical decision; he is a relativist to be sure, but a rational relativist, on who thinks before breaking a basic ethical rule.

\section{Normative Perspective}

The meaning of normative theories of the press can be captured in the statement of (Siebert et al 1956:1) as cited by Folarin 1998. 27) that 'the press always takes on the form and colloration of the social and political structures within which it operates'.

The normative theories of the press are at present six-namely: authoritarian media theorywhich exist to serve the government in power either as private or public (Raufu 2003:99), Societ-communist media theory-controlled by the communist party because the working class (proletariat) controlled power to maintain "peace" which necessitates monitoring the means of conveying thoughts and meanings in the society (Aina 2003:168); Free press theory (Libertarian)-characterized by 'free market place of ideas, where in the words of John Milton, "if ideas were freely published the best ones would win out". Social responsibility media theory- implies a recognition by the media that they must perform a public service to warrant their existence (Ahuja 1979: 10); Democratic-participant media theory- which preaches grass root media; (Raufu Opcit: 111); and Development media theory- which discourages negative use of the mass media (Aina Opcit:172).

Social responsibility is hereby emphasized considering its central importance to the issue at hand. Many literature hold that the theory has its root from the Hutchins Commission on Freedom of the Press, set up in the USA in 1947 to re-examine the press freedom in the Libertarian system and its birth was also influenced by the findings of the Royal commission of the Press set up in Britain in 1949. The chief duty of the media operating with this theory is to raise conflict to the place of discussion. Although the theory continues to emphasize freedom, it holds that responsibility is necessarily a partner to freedom in institutional 
behavior. Codes of ethics are encouraged as a self-regulatory device to promote social responsibility. (Day 2006:37). The relevance of this theory is further emphasized thus:

The development of a responsible depends on how well the concept of the press is understood by the public... there is need for intelligent planning of the objective and the goals, rules of operating, code of ethics, self-discipline etc to go a long way towards establishing a responsible press which may not need official restriction.

\section{Conceptual Framework}

Some relevant concepts such as ethics, public sphere, public opinion, perception and cognition, and stereotype are hereby clarified for better understanding

\section{Ethics}

Ethics is a moral concept. There is a consensus among philosophers that ethics is synonymous with morality and both involve human action (conduct, behavior) (Pratt, 1988). The word 'ethics' comes from the Greek word 'ethos' which means character, while the word 'morals' comes from the Latin word 'moralist' which means custom or manner (Okunna: 2003). For along time, the issue of ethics was tied directly to religion but such philosophers as Aristotle and Immanuel Kant have succeeded in producing ethical philosophies that are independent of any religion. However, the issue of what the ideal or good life should be has led to emergence of different schools of thought not only in the definition of ethics but also its understanding and categorization (Joseph 1973:3).

According to Frankena and Granrose (1974) "ethics" "stands for a branch of philosophy or philosophical thinking about morality and its problems'. Ethics as moral philosophy is therefore; that branch of knowledge which is concerned with the standards of good or bad conduct in the society, using societal norms as a basis for the evaluation of human conduct or behavior (Okunna Op cit). Allen and Voss (1997) also document the following conceptions about ethics.

* It is the art of setting standards of conduct and making moral judgments (Jimmie Killingworth).

* The study of the principles of conduct that apply to an individual or a group. The principles are rights, justice and utility (Mike Markel).

* To be ethical simply means to follow the laws and that concern for the consumer and citizen should remain foremost in relation to business. 
* Ethics according to Omole (2000) as cited by Okunna (2003:2) is defined as "the shared normative values, which any society holds dear and are used to judge the behavior or performance of any member of a society. It sets out the minimum of acceptable behavior which any member should attain to be regarded as a good ambassador of that society ".

Because ethics is concerned with such concepts as virtue and vice, right and wrong, good and bad, responsible and irresponsible, a study of the ethics is a study of all those rules and guidelines which are designed to regulate the actions of human beings as they make moral decisions. As such, answering the question of ethical compliance by media men and women in order to enjoy public trust and confidence cannot be overemphasized. Journalists principally perform their fundamental duties to ensure among other things, societal integration and cohesion, make government and its agencies accountable to the society as well as attaining societal sanity and development.

\section{The Public Sphere}

In the analysis of great German Scholar, Jurgen Habermas, the concept of public sphere directs attention to the historical evolution of the democratic role of the press in the society at large. As recorded in the pages of much literature, the practical reality of this concept came into being in England, France as facilitated by the print media especially the newspaper.

Putting into proper conception, Oso (2011) cites McQuail (2010) and Garnham (1986) who both conceptualize thus:

The public sphere is described as a space between the economy and the state providing an autonomous and open forum for public debate. Access to the space is free and freedom of association and assembly is guaranteed. The basic principles underlying the constitution and functioning of the public sphere include "general accessibility especially to information, the elimination of privilege and the search for general norms and their rational legitimation.

Oso op cit also notes that the concept of public sphere attracts the attention of Calhoun (1982) who pointed out that a public sphere adequate for a democratic polity must meet two requirements; quality of discourse and quality of participation. Individuals participate in the public sphere on the basis of equality; in principle it was open to all, "membership of the public sphere being conterminous with citizenship". These two requirements according to 
Schudson (1992) are central. "It is not just that people must participate but the quality of such participation and involvement is also as crucial" (Oso, 2011). It is on the basis of this that Habermas' theory stresses the importance of rational-critical discourse in the public sphere. Having become the main institution of the public sphere, the press is expected to function "as an instrument or a forum for the enlightened, rational, critical, and unbiased public discussion of what the common interests were in the matters of culture and politics" (Gripsund, 1992, p.89, cited by Oso, 2011, p.3).

It then goes to show that mass media and media practitioners as well as journalists are key players within the framework of public sphere. In actual fact, much is expected from journalists in this situation as correct, true and undistorted information must be made available to all members of the public without discrimination. This therefore calls for high degree of objectivity, fairness, sense of responsibility and accountability. But where unethical practices such as brown envelope syndrome, moonlighting, junketing, PR-journalism are all in the centre stage, the public will be the victims.

\section{Public Opinion}

According to Hornby (2000, p.,942), public is 'a group of people who share a particular interest or who are involved in the same activity'. Public according to Salu (1994) as quoted by Raufu (2005:17) is a 'group of people who by their activities will influence the person concerned or are themselves influenced by the person'. On the other hand, opinion is 'your feelings or thought about somebody or something, rather than fact' (Hornby, Op cit). it is also the 'expression of an attitude on a particular topic'. When attitude becomes very strong, it transforms to be opinion. Strong opinion can lead to verbal or behavioral actions.

Public opinion therefore is the general expression of an attitude on a particular topic by a group of people who share common interest in issue or the beliefs or views of a group of people (Hornby, Op cit, p. 819). Public or audience of media is large, dispersed and heterogeneous. They are unnatural phenomena. They do exist in nature, but are created in the course of human interactions with each other and with the technologies we invent to make our communications more enjoyable and entertaining, more powerful, fast and efficient (Nightingale and Ross (2003:1). They also propose that there are at least five dimensions to all research about audiences. They include: the people involved; their activities; the media 
material with which they engage; the media time/space in which the engagement occurs; and the media power structure that delimits the control that each stakeholder in a media event can wield.

As observed, members of the public in Nigerian society are such that are informed, vibrant, observant and highly involved in the scheme of things in the entire polity. Therefore, they can properly adjudge any social institution mass media inclusive as performing or otherwise on the basis of many parameters especially ethical consideration. Therefore, it behoves every journalist to be ethical compliant in the course of discharging their professional duties because, the opinions of the public is quite germane as this will go a long way in determining the level of public trust and confidence journalists would enjoy in the society.

\section{Cognition}

No doubt, the cognition of members of the public would definitely determine their perception about journalism and journalists themselves. Since as the fourth estate of realm, journalism is meant to serve the society in all ramifications, the performance of journalists is very critical in the whole process. As noted by Hornby, (2000, P.213) cognition is the process by which knowledge and understanding is developed in the mind. According to Baron et al; (1980) as cited by Aina (2006, p. 38), cognition is the process of knowing, perceiving or gaining knowledge about a phenomenon. It is a process of knowing the world outside us, by forming some mental representation of it. The cognition process, which is derived from certain internal activities, enables us make a sense of the world. For example, an average human being develops within him or herself internal cognition maps, which he or she uses to interpret and structure daily occurrences.

He further stated that these internal activities influence the judgment of people, or their particular behavior, events, policies, organizations (i.e attitude objects) as either favorable or unfavorable. By this, an individual fallback on variable like past experiences, values and certain ideas already part of him, to interpret others' behavior. The interpretation derived, though not always accurate, partly determines our typification or categorization of others. Perception is therefore a forum of cognition process. So, a goal oriented journalist must be conscious of this concept within the phenomenon of public sphere. 


\section{Perception}

This is the process of acquiring, interpreting, selection, and organizing sensory information. The word perception comes from the Latin word - percepio, meaning 'receiving, collecting, action of taking possession, apprehension with the mind or senses (Wikipedia Encyclopedia). Perception is also defined by Hornby (Op cit p.864) as 'the way you notice things, especially with the senses', 'the ability to understand the true nature of something, an idea, a belief or an image you have as a result of how you see or understand something'.

Brooks (1976:53) views perception as the aggregate of those physical, social and psychological notions and impressions that we have derived from our experience and our interaction with others. Our perceptions of others set the stage for all our later dealings with them. According to Baron et al (1980) as cited by Aina (2006:40), our perceptions of their feelings, intentions, and traits strongly affect the way in which we react to them. In fact, it is hard to imagine any aspect of our social relations that is not strongly influenced by such perceptions. Average Nigerian perceives journalists as being corrupt going by the rate of unethical practices prevalent among them (journalists). It is quite nagging to note that some journalists interviewed confessed that there is no more true practice of journalism rather, what is being practiced is PR-journalism or commercialized journalism.

\section{Stereotypes}

Hornby stereotypes as a fixed ideas or image that many people have of a particular type of person or thing, but it often not true in reality' Stereotype is one of the cognitive structures which involve a lot of generalization from limited data. Aina, (Op cit p.49) equally notes that 'stereotypes are perception device, which enable us to categorize others quickly without concentrating on their distinguishing features or individual variations. It is described as a 'lazy man perception' since they are over generalized belief based on limited evidence. They are generalizations based on a limited set of experience, which may be true at group level, but untrue at individual level. They are based on what we have abstracted from one or two incidents about how other behave in terms of their social background, age group, sex role, and callings.

Aina (2006:49) identifies negative and positive use of stereotypes. Negative stereotype can be used to confirm or rationalized prejudice about members of our groups. To achieve this, the 
stereotype holders who have a personal need can adjust the facts about others until they fit into the certain traits possessed by them. The stereotype holders do not bother to check their perception against new evidence or reality. Stereotyping can be particularly harmful when those being stereotyped unconsciously begin to behave in accordance with the image created by the stereotype holder. On the other hand, positive stereotype provides with a quick and fairly accurate guide or information about other people and situations; since it is practically impossible to deal with every person or situation uniquely.

These working stereotypes therefore, enable us to reduce the array of occurrences or phenomena in the life to manageable categories. It must be noted that it is not every time that is done with malice or ill will. It is only a perceptual device to cope with the strain of differentiation among the vast array of events and in our social universe. Essentially, cases of unethical practices among Nigerian journalists no doubt has led to public stereotype so much that it is a common generalization that every journalist lives on brown envelope and journalists in the country have largely become political praise singers.

\section{Journalism: Mirroring the Society}

One of the major cardinal functions of journalism or mass media in general is to mirror the society through its watchdog role. Therefore, the role of journalism in the society cannot be over-emphasized. Importantly, journalists or media practitioners must equally be conscious of the fact that they too are being mirrored by the public in general. As such, journalists must fulfill their fundamental obligations as defined by Harold Laswell. Laswell (1948) as cited by Folarin (2002, p. 58) gave the functions of the media as surveillance of the environment (the news function), correlation of the different parts of the environment (the editorial function) and transmission of the cultural heritage from one generation to the other (the culture transmission function).

These basic roles confer special and sensitive status on journalists in the society implying that to uphold the sanctity of the profession and constructive performance of these functions, any form of unethical practice should be eschewed or be reduced to the bearest minimum. This is more emphasized considering the analysis of Walter Lippman on the role of journalism in the society. Lippman notes that journalism role is to act as a mediator or translator between the 
public and policymaking. The journalists become the middleman. When elites speak, journalists listen and record the information, distil it, and pass it on to the members of the public for their consumption. The reasoning behind this is that the public is not in a position to deconstruct a growing and complex flurry of information present in modern society, and so an intermediary is needed to filter news for the masses (Wikipedia Encyclopedia). Though, this paradigm has been disproved in a way with the emergence of the concept of citizen journalism and advancement of technologies which brought about some social media like Facebook, Twitter, Myspace and the use of internet in general. Yet, the importance of journalists cannot still be debated as mediators and translators of social realities.

\section{Conclusion}

Considering the overwhelming roles of journalism in the society, there is need for high degree of sense of social responsibility among journalists so as to make all appreciate these obvious values of journalism in the society. It is therefore essential to remind journalists of the sacrilege message of Pope John Paul 11 to them (journalists) during his last visit to Nigeria and Africa. The spiritual personage submitted that the mass media are agent of national development and enjoined them to follow the social responsibility theory of the press as a means of advancing African society on developmental issues (Cited by Akinfeleye 2008, p. 59). In the words of the Pope, it reads further:

Here you are in the initial stages of development while the more industrialized countries have already reached a high level of development in this sector. This situation increases your responsibility, while giving you a unique opportunity through your mass media systems to contribute decisively to the service of man and total development of Africa (Ibid)

In view of this, there is need for deep rethinking by journalists especially in Nigeria on the imminent implications of unethical practices. No doubt, the major corollary losses are the questions of objectivity, public trust and public confidence and as a matter of fact; these are the sanctified and cardinal pillars of journalism which must be preserved, upheld and protected at all times. But if the situation continues this way without proper attention by all stakeholders to find lasting remedy to eliminate or reduce these ills among journalists, the profession will end up as an anathema as in the case of police institution. Hence, journalists across the federation need to redefine their personality in line with what the profession stands 
for and toe the line of greatness laid down by worthy forerunners of journalism in Nigeria and beyond. 


\section{References}

Ahuja, B.N., (1979). Theory and Practice of Journalism, Kamla, Delhi Surject Publication Aina, Sina (2003). Anatomy of Communications, Abeokuta Nigeria, Julian Publishers Aina, Sina (2004): Intermediate Newswriting and Reporting, Abeokuta, Nigeria Julian Publishers,

Aina S. (2006): Interacting With Others: Perspectives in Interpersonal Communication, Lagos Nigeria, Frontgate Publishers,.

Akinfeleye, R. (2005): Journalistic Integrity in Political and Economic Reporting, Paper Presented at the Nigerian Press Council National Workshop on Reporting Politics and the Economy, Ajah-Epe, Lagos, Nigeria.

Akinfeleye, R., (2008). Media Policy: Tool for National Development in Contemporary Isuues in Mass Media for Development and National Security (ed.) Akinfeleye R., Lagos Nigeria, Malthouse Press Limited

Allen, L. and Voss, D. (1997): Ethics in Technical Communications; Shades of Gray, John Wiley \& Sons, Inc., USA.

Belsey, A. (2003). Journalism and ethics: Can they Co-exist? In Kieran Mathew (ed) Media Ethics, London Routhledge,

Bunuola, L. (2005): Beat Journalism and the Role of Professional Ethics, a Paper Presented at the Nigerian Press Council National Workshop on Reporting Politics and the Economy, Ajah, Lagos.

Constitution of the federal republic of Nigeria, 1999

Davidoff, L.(1987): The Cambridge Encyclopedia of language, the Cambridge University Press, Great Britain.

Day, A. L. (2006): Ethics in Media Communication; Cases and Controversies, $5^{\text {th }}$ edition, USA, Thompson Higher education,.

Dominick, J. R. (2005): The Dynamics of Mass Communication, New York, USA, McGraw Hill,

Faruk, I. M. (2005): Public Perception of Media Reporting, Paper Presented at the Nigerian Press Council Workshop on Reporting Politics and Economy, Ajah, Lagos.

Folarin, B. (2002): Theories of Mass Communication: An Introductory Text, Abeokuta, Nigeria Link Publications

Frankena, W.K. and Granrose J.T. (eds.), (1974): Introductory Readings in Ethics, New 
Jersey, Engle Wood Cliffs, Prentice Hall

Hornby, A.S (2000), Oxford Advanced Learner's Dictionary of Current English, Oxford,

University Press Oxford

Joseph, B. (1973). Ethics and Morals, New York, Harper and Row

Kieran M. (ed.) (2003). Media Ethics, London, Routledge

MacBride, S., et al (1981) Many Voices, One World, Nigeria, Ibadan University Press.

Merrill J. and Barney R.D.(eds.): Ethics and the Press, New York, Hastings House

Nigerian Press Council, (1998) Code of Conduct for Nigerian Journalists, Nigerian Press Council Publications

Odunewu, A. (2000): Regulatory Mechanism, Lagos, Nigerian Press Council Publications

Okunna, C. S. (2003). Ethics of Mass Communication (Second edition), Enugu, Nigeria, New Generation,

Omole, G. (2000). The Place of the Nigerian Press Council, in Ethics and Regulations

Formulation: a Working Agenda for Journalists and the Media, Press Center International.

Oso, L. (2000). Including ethics Standards through Education and Retraining in Ethics \&

Regulation: Formulating a Working Agenda for Journalist and the Media, International Press Centre, Lagos.

Oso L. (2011). Mass Media and Democracy in Nigeria: The Prospect of a Pan-Nigerian

Public Sphere, Paper Presented at Des Wilson Conference on Communication at the University of Uyo, Nigeria on the 17th and 18th, March, 2011

Pratt, C. B. (1988). Responsibility and Ethical Reasoning in the Nigerian Press, African Media Review, Vol. 2, no 2

Potter, D. (2006). Handbook on Independent Journalism, Washington DC: Us Department of State, International Programs

Raufu, G. (2003). Mass Media and the Society; Issues \& Perspectives, Nigeria, Meek Associates, Surulere, Lagos

Raufu, G. (2005). Public Relations Principles, Nigeria, Meek Associates, Surulere, Lagos

Wikipedia, the Free Encyclopedia, http:/www.en.wikipedia. org/wiki/

Wilmot, P. (2006). Broadcasting, Agenda Setting and the Integrity Question, Paper Presented at the Biennial African Conference, Abuja, The News Magazine, Feb., 05, 2006. 